\title{
Efficient Copper-Catalyzed Trifluoromethylation of Aromatic and Heteroaromatic lodides: The Beneficial Anchoring Effect of Boranes
}

\author{
Zsombor Gonda, Szabolcs Kovács, Csaba Wéber, ${ }^{\dagger}$ Tamás Gáti, ${ }^{\dagger}$ Attila Mészáros, András Kotschy, ${ }^{* \dagger}$ \\ Zoltán Novák*
}

MTA-ELTE „Lendület” Catalysis and Organic Synthesis Research Group, Institute of Chemistry, Eötvös Loránd University, Pázmány Péter stny. 1/a, H-1117 Budapest, Hungary

${ }^{\dagger}$ Servier Research Institute of Medicinal Chemistry, Záhony utca 7. Budapest, Hungary

Supporting Information Placeholder

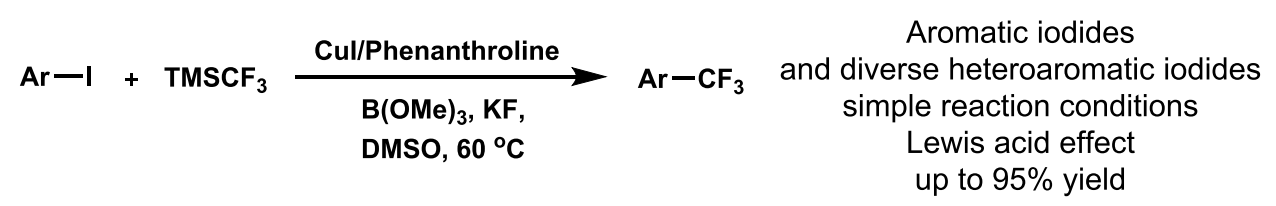

Efficient copper-catalyzed trifluoromethylation of aromatic iodides was achieved with TMSCF $_{3}$ in the presence of trimethoxyborane. The Lewis acid was used to anchor the in situ generated trifluoromethyl anion and suppress its rapid decomposition. Broad applicability of the new trifluoromethylating reaction was demonstrated in the functionalization of different aromatic and heteroaromatic iodides.

Due to their unique physical and biological properties compounds bearing the trifluoromethyl functional group have attracted significant attention in medicinal research, agrochemistry and materials science. ${ }^{1}$ While the importance of this group is unquestionable, the introduction of the trifluoromethyl group into organic molecules in most cases is very challenging. The most important issues faced by trifluoromethylation reactions are the application of cheap, stable and readily available reagents, and the development of efficient, scalable, and selective processes. Trifluoromethylation has been achieved via transition metalcatalyzed oxidative couplings, ${ }^{2}$ radical functionalizations, ${ }^{3}$ and in cross-coupling reactions. Besides the palladium catalyzed directed functionalization of aryl halides, ${ }^{4}$ several copperbased stoichiometric ${ }^{5}$ and catalytic methods were developed recently for the introduction of the trifluoromethyl group onto the aromatic core. The first copper catalyzed trifluoromethylation of iodides in the presence of a $\mathrm{CuI} /$ phenanthroline catalyst was reported by Amii and coworkers. ${ }^{6 a}$ Though this catalytic reaction works efficiently, the use of expensive and relatively inaccessible $\mathrm{TESCF}_{3}$ as the trifluoromethyl source makes this process less economic, especially for large scale syntheses. Later, Goossen utilized $\mathrm{K}\left[\mathrm{CF}_{3} \mathrm{~B}(\mathrm{OMe})_{3}\right]$ for copper catalyzed trifluoromethylation. ${ }^{6 c}$ While this salt works efficiently, its sensitivity and instability limits its application. ${ }^{7}$

To circumvent the drawbacks of trifluoromethylborate salts and $\mathrm{TESCF}_{3}$, we aimed to develop a new procedure in which the relatively cheap and readily available $\mathrm{TMSCF}_{3}$ is used as the trifluoromethyl source. The major problem with the application of $\mathrm{TMSCF}_{3}$ in combination with a fluoride source is the rapid generation of large amounts of the $\mathrm{CF}_{3}{ }^{-}$anion. Since the catalytic transformation is relatively slow, a significant amount of active $\mathrm{CF}_{3}^{-}$is lost before entering the catalytic cycle. A potential solution to this problem would be the reversible quenching of the $\mathrm{CF}_{3}^{-}$anion by the addition of a Lewis acid species, which would protect the rapidly produced trifluoromethyl anion and release it only slowly (Scheme 1). A good buffer system should be stable enough to stabilize the $\mathrm{CF}_{3}$ ion, while still labile enough to transfer $\mathrm{CF}_{3}$ to the copper cycle.

Scheme 1. Lewis Acid-buffered copper-catalyzed trifluoromethylation

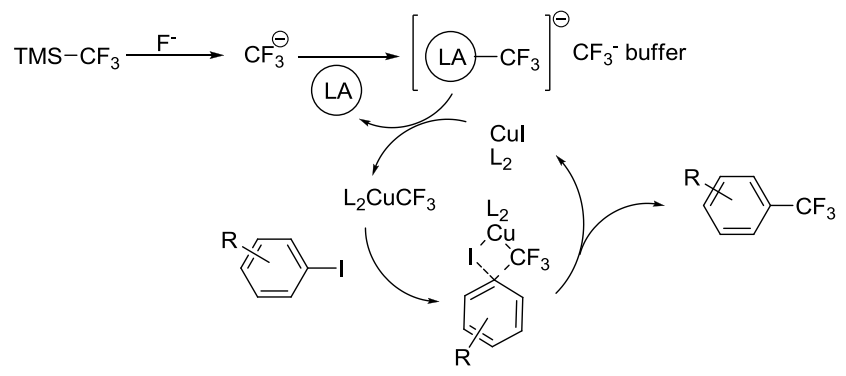

As a starting point we examined the trifluoromethylation of 1-iodonaphthalene with 3 eq. $\mathrm{TMSCF}_{3}$ and 3 eq. $\mathrm{KF}$ in the presence of $20 \% \mathrm{CuI}$ and $20 \%$ phenanthroline ligand. The Lewis acid free reaction gave only $15 \%$ conversion in 2 hours (Table 1. Entry 1.) that remained the same after 24 hours. This finding is in agreement with the rapid $\mathrm{KF}$ triggered formation and decomposition of the $\mathrm{CF}_{3}$ anion. ${ }^{8}$ When we used 1 eq. of 
$\mathrm{TMSCF}_{3}, \mathrm{KF}$, and $\mathrm{B}(\mathrm{OMe})_{3}$ the conversion increased to $36 \%$ after 2 hours at $60{ }^{\circ} \mathrm{C}$ (Entry 2.), but the reaction stopped again. When we increased the amount of $\mathrm{TMSCF}_{3}$ and $\mathrm{KF}$ to 3 equivalents while maintaining $\mathrm{B}(\mathrm{OMe})_{3}$ at 1 equivalent (Entry 3.) the conversion rose to $70 \%$, clearly demonstrating the buffering ability of the borate.

Table 1. Optimization studies ${ }^{\text {[a] }}$

\begin{tabular}{|c|c|c|c|c|c|}
\hline & + & $\begin{array}{r}\mathrm{CF}_{3}+\mathrm{KF} \\
3\end{array}$ & 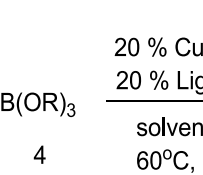 & & $\mathrm{CF}$ \\
\hline $\begin{array}{l}\text { En- } \\
\text { try }\end{array}$ & Solvent & Ligand & Borane & $\begin{array}{l}2: 3: 4 \\
\text { ratio }\end{array}$ & $\begin{array}{c}\text { conv. } \\
{[\%]} \\
{[\mathrm{b}]}\end{array}$ \\
\hline 1 & DMSO & Phen & - & $3: 3: 0$ & 15 \\
\hline 2 & DMSO & Phen & $\mathrm{B}(\mathrm{OMe})_{3}$ & $1: 1: 1$ & 36 \\
\hline 3 & DMSO & Phen & $\mathrm{B}(\mathrm{OMe})_{3}$ & $3: 3: 1$ & 70 \\
\hline 4 & DMSO & Phen & $\mathrm{B}(\mathrm{OMe})_{3}$ & $3: 3: 3$ & 92 \\
\hline 5 & DMSO & $\mathrm{Me}_{4}$-Phen & $\mathrm{B}(\mathrm{OMe})_{3}$ & $3: 3: 3$ & 81 \\
\hline 6 & DMSO & $\begin{array}{l}\text { 8-OH- } \\
\text { Quinoline }\end{array}$ & $\mathrm{B}(\mathrm{OMe})_{3}$ & $3: 3: 3$ & 0 \\
\hline 7 & DMSO & sparteine & $\mathrm{B}(\mathrm{OMe})_{3}$ & $3: 3: 3$ & 13 \\
\hline 8 & DMSO & Phen & $\mathrm{B}(\mathrm{OEt})_{3}$ & $3: 3: 3$ & 85 \\
\hline 9 & DMSO & Phen & $\mathrm{B}\left(\mathrm{OCH}_{2} \mathrm{CF}_{3}\right)_{3}$ & $3: 3: 3$ & 2 \\
\hline 10 & DMSO & Phen & $\mathrm{B}(\mathrm{OPr})_{3}$ & $3: 3: 3$ & 64 \\
\hline 11 & DMSO & Phen & $\mathrm{B}\left(\mathrm{O}^{\mathrm{i}} \mathrm{Pr}\right)_{3}$ & $3: 3: 3$ & 10 \\
\hline 12 & DMSO & Phen & $\mathrm{B}(\mathrm{OBu})_{3}$ & $3: 3: 3$ & 48 \\
\hline 13 & DMSO & Phen & $\mathrm{B}\left(\mathrm{O}^{\mathrm{t}} \mathrm{Bu}\right)_{3}$ & $3: 3: 3$ & 37 \\
\hline
\end{tabular}

[a] $\mathrm{CuI}(0.07 \mathrm{mmol}), 1,10$-phenanthroline $(0.07 \mathrm{mmol})$, aryl iodide $(0.35 \mathrm{mmol})$ in $1 \mathrm{~mL}$ anhydrous Solvent at $60{ }^{\circ} \mathrm{C}, \% \mathrm{GC}$ yield $[\mathrm{b}]$ conversions were determined by GC-MS

To our delight, when $\mathrm{TMSCF}_{3}: \mathrm{KF}: \mathrm{B}(\mathrm{OMe})_{3}$ were applied in $3: 3: 3$ equivalents ratio the reaction reached $92 \%$ conversion in 2 hours (Entry 4.). ${ }^{9}$ Next, we examined the effect of the ligand and the Lewis acid on the reaction. Only the phenanthroline based ligand proved to be applicable for the transformation (Entries 4-7.). Variation of the Lewis acid showed that the bulkier the alkyl group on the borane the less able it is to stabilize the $\mathrm{CF}_{3}$ anion, resulting in a lower conversion. Changing the methyl group to ethyl resulted in $81 \%$ conversion (Entry 8.), while the use of propyl, iso-propyl, butyl and tert-butyl borates led to $64 \%, 10 \%, 48 \%$ and $37 \%$ conversion respectively (Entries 10-13.). Replacement of ethyl group with 1,1,1trifluoroethyl group, the borane become completely uneffective in the coupling due probably to its increased electron deficiency (Entry 9.). ${ }^{10}$ To identify the optimal conditions for the trifluoromethylation of 1-iodonaphthalene the temperature, copper loading, fluoride source and the solvent were also varied. As a result of this multi dimension parameter screening we found that the use of $20 \mathrm{~mol} \% \mathrm{CuI}$ as copper source, 20 mol\% 1,10-phenanthroline as ligand, KF as fluoride source, and anhydrous DMSO as solvent are optimal for the coupling that is best run under argon at $60{ }^{\circ} \mathrm{C}$. With these conditions in hand we explored the scope and limitations of the Lewis-acid enabled copper-catalyzed trifluoromethylation.

The functional group tolerance of the transformation was established on a set of 21 aromatic and heteroaromatic iodides having different electronic and steric properties, as well as protecting groups. In the first round the reactions were analyzed by GCMS. ${ }^{11}$ On the basis of these studies we established that the trifluoromethylation can be achieved with aryl iodides containing both electron donating and electron withdrawing groups, however in the latter case the reactions were faster. The presence of bulky substituents in orto position was also tolerated, however longer reaction times were necessary to reach complete conversion. We have also established that for the successful coupling free hydroxyl and amino groups (including indoles) should be protected.

Having established the functional group tolerance we aimed to prove the synthetic utility of the Lewis-acid enable trifluoromethylation by preparing a diverse set of trifluoromethylated compounds, including heterocyclic derivatives (Scheme 2.). To demonstrate the applicability of the method for the trifluoromethylation of functionalized aromatic iodides we performed successfully the trifluoromethylation of a protected phenol and two protected anilines, and isolated the appropriate products $\mathbf{4 a}, \mathbf{4 b}$, and $\mathbf{4 c}$ with $67 \%, 68 \%$ and $35 \%$ yield respectively. Ester and amide derivatives of aromatic carboxylic acids did also prove to be excellent substrates, and their trifluoromethyl substituted derivatives $(\mathbf{4 d}, \mathbf{4 e})$ were obtained in moderate to good yield $(34 \%, 81 \%)$.

The application of pyridine derivatives bearing ester-, protected alcohol- and halogene functions beyond the iodo group resulted the desired products $\mathbf{4 f}, \mathbf{4 g}$ and $\mathbf{4 h}$ with good to excellent yield $(59 \%, 92 \%$ and $71 \%)$. The reaction was also successful with 6-iodo-4-methyl-2-(methylthio)-pyrimidine and the trifluoromethylated compound was isolated with $90 \%$ yield (4i). In the case of 1-benzyl-4-iodopyrazole and sterically hindered 1-benzyl-3,5-diphenyl-4-iodopyrazole the reactions were not complete ( $87 \%$ and $68 \%$ conversion) but the desired trifluoromethylated products $\mathbf{4 j}$, $\mathbf{4 k}$ were isolated with $60 \%$ and $34 \%$ yield. Functionalization of 1iodoisoquinoline and 6-iodoquinoline gave the desired trifluoromethylated isoquinoline (4I) and quinoline $(\mathbf{4 m})$ in $82 \%$ and $64 \%$ yields. We also prepared the quinoline $4 \mathbf{n}$ bearing bromo substituent next the trifluoromethyl group $(32 \%)$. The analogous chloro-iodo-quinoline derivatives gave the appropriate trifluoromethylated products $\mathbf{4 o}, \mathbf{4 p}$ and $\mathbf{4 q}$ with good yields $(95 \%, 74 \%$ and $80 \%)$. The coupling of benzyl protected indole derivatives, 5-iodoindole, 7-iodoindole and 5methoxy-3-iodoindole afforded the appropriate products $(4 \mathbf{r}$, 4s, 4t) with $72 \%, 88 \%$ and $30 \%$ isolated yields respectively.

The reaction of $N$-benzyl protected derivatives of $\mathrm{N}$ heterocycles such as 3-iodo-7-azaindole, 4-iodoindazole, 6chloro-7-iodo-7-deazapurine and 4-iodocarbazole resulted the appropriate heterocycles $\mathbf{4 u}, \mathbf{4 v}, \mathbf{4 w}$ and $\mathbf{4 x}$ with good yields $(94 \%, 87 \%, 27 \%$ and $87 \%)$. Iodo derivatives of benzofuran and dibenzofuran reacted smoothly under the optimized conditions. Trifluoromethylation of 2-methyl-5-iodobenzofuran gave the appropriate product $(4 y)$ with $62 \%$ isolated yield, while in an analogous reaction 2-(trifluoromethyl)dibenzofuran (4z) was isolated with $86 \%$ yield. Replacement of the oxygen in the heterocyclic compound by sulfur did not cause significant changes in reactivity and 2-ethyl-5trifluoromethyl benzothiophene (4aa) was obtained in $69 \%$ yield. For comparison we have also performed the trifluoromethylation on the carbacyclic compound 2iodofluorene, and we isolated the trifluoromethylated product (4ab) only in $21 \%$ yield. 
Scheme 2. Synthesis of trifluoromethylated compounds in copper catalyzed trifluoromethylation ${ }^{\text {a }}$

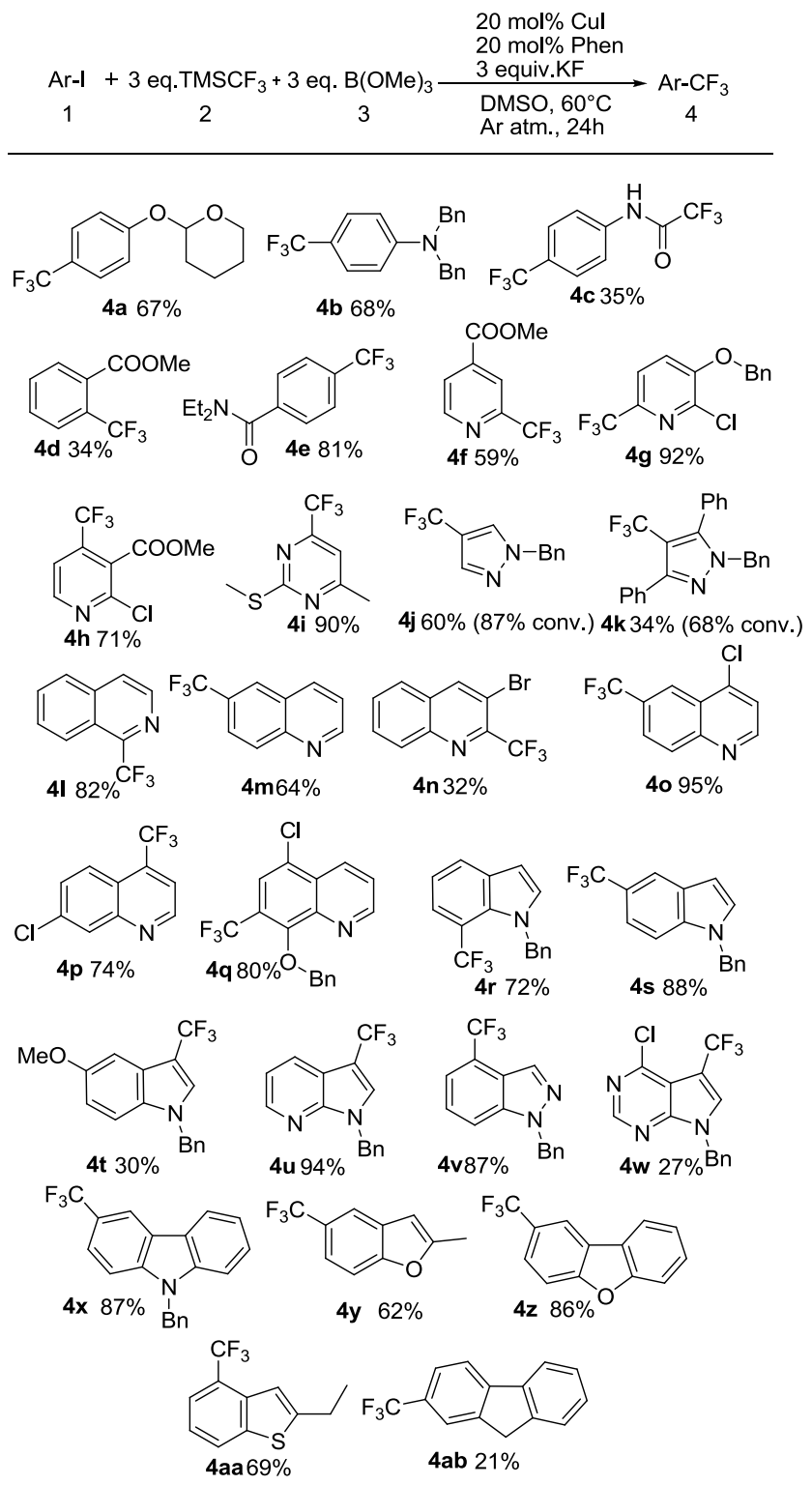

${ }^{\text {a }} \mathrm{CuI}(0.4 \mathrm{mmol}), 1,10$-phenanthroline $(0.4 \mathrm{mmol}), \mathrm{KF}$ (6 mmol.), aryl iodide (2.00 mmol,), DMSO (anh., $4.0 \mathrm{~mL}) \mathrm{B}(\mathrm{OMe})_{3}$ (6 mmol, ), $\mathrm{TMSCF}_{3}(6 \mathrm{mmol}), \mathrm{Ar}, 60^{\circ} \mathrm{C}, \%$ isolated yield

Regarding the beneficial effect of trimethoxy borane in the coupling reaction we monitored the reaction by in situ NMR measurements. We supposed that the liberation of trifluoromethyl anion from $\mathrm{TMSCF}_{3}$ takes place quickly by interaction with fluoride anion, but in the presence of borane a significant part of the formed $\mathrm{CF}_{3}{ }^{-}$anion is stabilized in situ by the borane. The formation of $\mathrm{CF}_{3}$-borane and $\mathrm{Cu}-\mathrm{CF}_{3}$ complexes was identified by ${ }^{19} \mathrm{~F}-\mathrm{NMR}$ measurements. The presence of a peak at $-29.2 \mathrm{ppm}$ refers to the presence of $\mathrm{Cu}-\mathrm{CF}_{3}$ species, while the peak at $-65.5 \mathrm{ppm}$ proved the presence of $\mathrm{CF}_{3} \mathrm{~B}(\mathrm{OMe})_{3}$. These findings support our hypothesis regarding the formation of Lewis acid-base adduct of the $\mathrm{CF}_{3}$ anion with trimethylborane.

In conclusion, we have developed a Lewis-base enabled approach for the copper-catalyzed trifluoromethylation of aromatic and heteroaromatic iodides. The transformation utilizes
$\mathrm{TMSCF}_{3}$ as a readily available $\mathrm{CF}_{3}$ source and trialkoxy boranes as Lewis acid for the temporary trapping of the $\mathrm{CF}_{3}{ }^{-}$ anion generated by KF from the trifluoromethylating agent. The transformation has a good functional group tolerance and its synthetic utility was demonstrated through the synthesis of several trifluoromethylated aromatic and heteroaromatic molecules. The advantage of the procedure is that it eliminates the use of expensive $\mathrm{TESCF}_{3}$ and unstable trifluoromethylborate salts, previously utilized as $\mathrm{CF}_{3}$ source in the copper-catalyzed trifluoromethylation. Moreover, the developed conditions offer an efficient synthetic tool for the introduction of trifluoromethyl group into aromatic and heteroaromatic rings, providing easy access to compounds of high added value for pharmaceutical research.

\section{ASSOCIATED CONTENT}

\section{Supporting Information}

Experimental procedures, characterization data and NMR spectra for all compounds. "This material is available free of charge via the Internet at http://pubs.acs.org."

\section{AUTHOR INFORMATION}

\section{Corresponding Author}

*novakz@elte.hu, andras.kotschy@hu.netgrs.com

\section{Author Contributions}

The manuscript was written through contributions of all authors. / All authors have given approval to the final version of the manuscript

\section{ACKNOWLEDGMENT}

The financial support of Servier, as well as the contribution of the Hungarian Academy of Sciences ("Lendület" Research Scholarship), and OTKA-NKTH (CK 80763) is gratefully acknowledged. The authors also thank Prof. Tim Peelen (Lebanon Valley College) for the proofreading of this manuscript.

\section{REFERENCES}

1 (a) Schlosser, M. Angew. Chem., Int. Ed. 2006, 45, 5432. (b) Müller, K.; Faeh, C.; Diederich, F. Science 2007, 317, 1881. (c) Hagmann,W. K. J. Med. Chem. 2008, 51, 4359. (d) Kirk, K. L. Org. Process Res. Dev. 2008, 12, 305. (e) Purser, S.; Moore, P. R.; Swallow, S.; Gouverneur, V. Chem. Soc. Rev. 2008, 37, 320. (f) Grushin, V. V.; Tomashenko, O. A. Chem. Rev. 2011, 111, 4475. (g) Roy, S.;Gregg, B. T.; Gribble,G.W.; Le, V.-D.; Roy, S. Tetrahedron 2011, 67, 2161. (h) Barata-Vallejo, S.; Postigo, A. Coord. Chem. Rev. 2013, 257, 3051. (i) Chen, P.; Liu, G. Synthesis, 2013, 45, 2919. (j) Ye, Y.; Sanford, M. S. Synlett 2012, 23, 2005. (k) Liu, X.; Xu, C.; Wang, M.; Liu, Q. Chem. Rev. 2014. ASAP. doi: 10.1021/cr400473a

2 (a) Wang, X.; Truesdale, L.; Yu, J.-Q. J. Am. Chem. Soc. 2010, 132, 3648. (b) Mu, X.; Chen, S.; Zhen, X.; Liu, G. Chem. Eur. J. 2011, 17, 6039. (c) Ye, Y.;Lee, S. H. Sanford, M. S. Org. Lett. 2011, 13, 5464. (d) Deb, A.; Manna, S.; Modak, A.; Patra, T.; Maity, S.; Maiti, D. Angew. Chem., Int. Ed. 2013, 52, 747. (e) Yang, Y.-D.; Iwamoto, K.; Tokunaga, E.; Shibata, N. Chem. Commun. 2013, 49, 5510. (f) Jiang, X.; Chu, L.; Qing, F.-L. J. Org. Chem. 2012, 77, 1251. (g) Chu, L.; Qing, F.-L. J. Am. Chem. Soc. 2012, 134, 1298. (h) Senecal, T. D.; Parsons, A. T.; Buchwald, S. L. J. Org. Chem. 2011, 76, 1174. (i) Yu, Q.; Ma, S. Chem. - Eur. J. 2013, 19, 13304. (j) Parsons, A. T.; Buchwald, S. L. Angew. Chem., Int. Ed. 2011, 50, 9120. (k) Chu, L.; Qing, F.-L. Acc. Chem. Res. 2014, 47, 1513 
${ }^{3}$ (a) Wakselman, C.; Tordeux, M. J. Chem. Soc., Chem. Commun. 1987, 1701. (b) Akiyama, T.; Kato, K.; Kajitani, M.; Sakaguchi, Y.; Nakamura, J.; Hayashi, H.; Sugimori, A. Bull. Chem. Soc. Jpn. 1988, 61, 3531. (c) Sawada, H.; Nakayama, M. J. Fluorine Chem. 1990, 46, 423. (d) Kirk, K. L.; Nishida, M.; Fujii, S.; Kimoto, H. $J$. Fluorine Chem. 1992, 59, 197. (e) McClinton, M. A.; McClington, D. A. Tetrahedron 1992, 48, 6555. (f) Kamigata, N.; Ohtsuka, T.; Fukushima, T.; Yoshida, M.; Shimizu, T. J. Chem. Soc., Perkin Trans. 1 1994, 1339. (g) Kino, T.; Nagase, Y.; Ohtsuka, Y.; Yamamoto, K.; Uraguchi, D.; Tokuhisa, K.; Yamakawa, T. J. Fluorine Chem. 2010, 131, 98. (h) Ji, Y.; Brueckl, T.; Baxter, R. D.; Fujiwara, Y.; Seiple, I. B.; Su, S.; Blackmond, D. G.; Baran, P. S. Proc. Natl. Acad. Sci. USA 2011, 108, 14411. (i) Nagib, D. A.; MacMillan, D. W. C. Nature, 2011, 480, 224. (j) Iqbal, N.; Choi, S.; Ko, E.; Cho, E. J. Cho Tetrahedron Letters, 2012, 53, 2005. (k) Studer, A. Angew. Chem., Int. Ed. 2012, 51, 8950. (1) Zhang, B.; MueckLichtenfeld, C.; Daniliuc, C. G.; Studer, A. Angew. Chem., Int. Ed. 2013, 52, 10792. (m) Zheng, Y.; Ma, J.-A. Adv. Synth. Catal. 2010, 352, 2745. (n) Liu, X.; Xiong, F.; Huang, X.; Xu, L.; Li, P.; Wu, X. Angew. Chem., Int. Ed. 2013, 52, 6962. (o) Mizuta, S.; GaliciaLopez, O.; Engle, K. M.; Verhoog, S.; Wheelhouse, K.; Rassias, G.; Gouverneur, V. Chem. - Eur. J. 2012, 18, 8583. (p) Parsons, A. T.; Buchwald, S. L. Nature 2011, 480, 184. (q) Li, Y.; Studer, A. Angew. Chem., Int. Ed. 2012, 51, 8221. (r) Ye, Y.; Sanford, M. S. J. Am. Chem. Soc. 2012, 134, 9034. (s) Feng, C.; Loh, T.-P. Chem. Sci. 2012, 3, 3458. (t) Janson, P. G.; Ilchenko, N. O.; Ghoneim, I.; Szabo, K. J.; Org. Lett. 2012, 14, 2882. (u) Ye, Y.; Kunzi, S. A.; Sanford, M. S. Org. Lett. 2012, 14, 4979. (v) Chen, Z.-M.; Bai, W.; Wang, S.-H.; Yang, B.-M.; Tu, Y.-Q.; Zhang, F.-M. Angew. Chem., Int. Ed. 2013, 52, 9781. (w) Yasu, Y.; Koike, T.; Akita, M. Chem. Commun. 2013, 49, 2037. (x) Li, Y.; Wu, L.; Neumann, H.; Beller, M. Chem. Commun. 2013, 49, 2628. (y) Cai, S.; Chen, C.; Sun, Z.; Xi, C. Chem. Commun. 2013, 49, 4552. (1) Merino, E.; Nevado, C. Chem. Soc. Rev. 2014. ASAP doi: 10.1039/c4cs00025k

${ }^{4}$ (a) Samant, B. S.; Kabalka, G. W. Chem. Commun. 2011, 47, 7236. (b) Cho, E. J.; Senecal, T. D.; Kinzel, T.; Zhang, Y.;Watson, D. A.; Buchwald, S. L. Science 2010, 328, 1679;

5 (a) Dubinina, G. G.; Furutachi, H.; Vicic, D. A. J. Am. Chem. Soc. 2008, 130, 8600. (b) Dubinina, G. G.; Ogikubo, J.; Vicic, D. A. Organometallics 2008, 27, 6233. (c) Chu, L.; Qing, F.-L. Org. Lett. 2010, 12, 5060. (d) McReynolds, K. A.; Lewis, R. S.; Ackerman, L. K. G.; Dubinina, G. G.; Brennessel, W. W.; Vicic, D. A. J. Fluorine
Chem. 2010, 131, 1108. (e) Zhang, C.-P.; Wang, Z.-L.; Chen, Q.Y.; Zhang, C.-T.; Gu, Y.-C.; Xiao, J.-C. Angew. Chem., Int. Ed. 2011, 50, 1896. (f) Morimoto, H.; Tsubogo, T.; Litvinas, N. D.; Hartwig, J. F. Angew. Chem., Int. Ed. 2011, 50, 3793. (g) Tomashenko, O. A.; Escudero, E. C.; Belmonte, M. M.; Grushin, V. V. Angew. Chem., Int. Ed. 2011, 50, 7655. (h) Liu, T.; Shen, Q. Eur. J. Org. Chem. 2012, 2012, 6679. (i) Hu, M.; Ni, C.; Hu, J. J. Am. Chem. Soc. 2012, 134, 15257.

${ }^{6}$ (a) Oishi, M.; Konda, H.; Amii, H. Chem. Commun. 2009, 1909. (b) Shimizu, R.; Egami, H.; Nagi, T.; Chae, J.; Hamashima, Y.; Sodeoka, M. Tetrahedron Lett. 2010, 51, 5947. (c) Knauber, T.; Arikan, F.; Roeschenthaler, G.-V.; Goossen, L. J. Chem.;Eur. J. 2011, 17, 2689. (d) Xu, J.; Luo, D.-F.; Xiao, B.; Liu, Z.-J.; Gong, T.-J.; Fu, Y.; Liu, L. Chem. Commun. 2011, 47, 4300. (e) Liu, T.; Shen, Q. Org. Lett. 2011, 13, 2342. (f) Kondo, H.; Oishi, M.; Fujikawa, K.; Amii, H. Adv. Synth. Catal. 2011, 353, 1247. (g) Xu, J.; Fu, Y.; Luo, D.-F.; Jiang, Y.-Y.; Xiao, B.; Liu, Z.-J.; Gong, T.-J.; Liu, L. J. Am. Chem. Soc. 2011, 133, 15300. (h) Liu, T.; Shao, X.; Wu, Y.; Shen, Q. Angew. Chem., Int. Ed. 2012, 51, 540. (i) He, Z.; Luo, T.; Hu, M.; Cao, Y.; Hu, J. Angew. Chem., Int. Ed. 2012, 51, 3944. (j) Shimizu, R.; Egami, H.; Hamashima, Y.; Sodeoka, M. Angew. Chem., Int. Ed. 2012, 51, 4577. (k) Xu, J.; Xiao, B.; Xie, C.-Q.; Luo, D.-F.; Liu, L.; Fu, Y. Angew. Chem., Int. Ed. 2012, 51, 12551. (1) Miyake, Y.; Ota, S.-i.; Nishibayashi, Y. Chem. - Eur. J. 2012, 18, 13255. (m) Egami, H.; Shimizu, R.; Kawamura, S.; Sodeoka, M. Angew. Chem., Int. Ed. 2013, 52, 4000. (n) Ambler, B. R.; Altman, R. A. Org. Lett. 2013, 15, 5578. (o) He, Y.-T.; Li, L.H.; Yang, Y.-F.; Wang, Y.-Q.; Luo, J.-Y.; Liu, X.-Y.; Liang, Y.-M. Chem. Commun. 2013, 49, 5687. (p) Miyake, Y.; Ota, S.-i.; Shibata, M.; Nakajima, K.; Nishibayashi, Y. Chem. Commun. 2013, 49, 7809 .

${ }^{7}$ On the basis of our experience the salt works only when it is freshly prepared. Upon storage, it quickly lost its activity in several days and become uneffective in trifluormethylation. For results of stability studies of trifluoromethyl borate salts, see Supporting Information)

${ }^{8}$ The in situ NMR studies showed the formation of $\mathrm{CHF}_{3}$ and $\mathrm{CDF}_{3}$.

${ }^{9}$ For time-conversion curves see Supporting Information

${ }^{10}$ For further details see Supporting Information

${ }^{11}$ Results of functional group tolerance study with GCMS in case of 21 substrates can be found in the supporting information. 